\title{
Alliance Formation and Dissolution: The Debates on NATO After the Cold War
}

\begin{abstract}
This paper examines the alliance formation and dissolution among the states in the context of NATO after the Cold War. The ending of the Cold War triggered a scientific battle between the theoretical positions of the international politics. One of the main dimensions of these theoretical debates has been the alliance formation and dissolution. The future of NATO became the theme that the theoretical approaches constitute their rightness. Neorealist, neoliberal institutionalist and constructivist theories were comparatively examined, and they were also criticised in connection with the context of these theories over the alliance formation and dissolution perspectives. Furthermore, the theoretical views were embraced in the case of NATO after the Cold War. After the examination of the literature and the main theoretical positions, I focused on the control management theory of Schroeder over the alliance formation and dissolution. He claimed that the states make alliances to control other states. I investigated this claim with the main theoretical perspectives about the alliances comparatively. I argued that NATO is a control management mechanism and its maintenance after the Cold War is strictly dependent on this characteristic.
\end{abstract}

\section{Key Words}

NATO, Alliance, Cold War, Neo Realism, Neo Institutionalism, Constructivism 


\section{İttifak Oluşumu ve Dağılması: Soğuk Savaș Sonrası NATO Üzerine Tartışmalar}

\section{Öz}

Bu çalışma devletler arasındaki ittifak oluşumunu ve dağılmasını Soğuk Savaş sonrası NATO bağlamında incelemektedir. Soğuk Savaş'ın sona ermesi uluslararası ilişkiler teorileri arasında bilimsel bir çatışmayı alevlendirmiştir. Söz konusu teorik tartışmaların en önemli boyutlarından biri, ittifak oluşumu ve dağılması olmuştur. NATO'nun geleceği teorik yaklaşımların kendi doğruluklarını dayandırdıkları bir tema haline gelmiştir. Neorealist, neoliberal kurumsalcı ve inşacı teoriler karşılaştırmalı olarak incelenmiş; ittifak oluşumu ve dağılması perspektiflerinden eleştirilmiştir. Daha sonra teorik fikirler Soğuk Savaş sonrası NATO örneğinde ele alınmıștır. Literatürün ve ana teorik fikirlerin değerlendirilmesinden sonra, Schroeder'in ittifak oluşumu ve dağılımı üzerine kontrol yönetimi teorisine odaklandım. Schroeder'e göre devletler diğer devletleri kontrol etmek için ittifak kurmaktadır. Bu iddiayı ittifaklara dair ana teorik perspektiflerle karşılaştırmalı olarak inceledim. Tez çalışmasında NATO'nun bir kontrol yönetimi mekanizması olduğunu ve Soğuk Savaş sonrasında varlığını sürdürmesinin onun bu karakteriyle güçlü şekilde ilişkili olduğunu iddia etmekteyim.

\section{Anahtar Kelimeler}

NATO, İttifak, Soğuk Savaş, Neo Realizm, Yeni Kurumsalcılık, Yapısalcılık 
The alliance formation literature has become one of the main controversial fields that host a scientific battlefield among the different theories of the international politics. The reason for this kind of theoretical clash is the importance of the subject. The importance of the alliances is its creative function in politics. Carl Schmitt depicts this creative role of the alliance formation as the duality between the friend and the enemy. For him, the politics is a struggle between the friend and the enemy. This duality is the basis of being political. (Schmitt, 2008) In this framework, the formation of alliances has been an important subject in international relations. This importance isn't limited to the theoretical boundaries, but it is also practical. The history is full of the successes and the fails of selecting the right or wrong allies and enemies. Stephen Walt depicted historical records that show how defining the allies, and the enemies have had a crucial role in shaping European history. (Walt, 1990, p. 2) Both theoretical debates and practical implementations of the ideas on the alliance formation have great importance to understand the phenomena and the events in the international politics. This importance can be so vital that the approaches and the interpretations about the alliances are one of the most important parts of thinking on international politics. In this sense, it can be argued that the alliance formation is at the centre of the international politics.

The end of the Cold War opened new debates and perspectives over the theories of alliance formation. Firstly, any theoretical approach or author could not predict the end of the cold war. It can be said that most interpreters of the international politics community were unready to discuss the future of the international politics in the context of post-Cold War. The transition period after the Cold War meant a test for theoretical approaches as well. This test almost became a scientific battle in the discipline of the international politics. The results of this outstanding transition in the human history were embraced to test assumptions and predictions of different theoretical approaches. One of the most important parts of this test happened to be the debates over the future of NATO.

NATO was established in 1949 and casus foederis, (the case for the alliance) was formulated in the $5^{\text {th }}$ article of its founding charter. According to $5^{\text {th }}$ article, the parties of the charter declared that armed attack against one or more countries that are a part of the alliance would be considered as an attack against all states. This article made NATO a perfect alliance, for the organisation guaranteed the survival that is the most vital priority of the states for a realist interpretation of Kenneth Waltz. (Waltz, 1979) NATO played a significant role in the Cold War for its members. Beyond a military alliance, as a means of technical and financial assistance, NATO was an organisation that gives a significant opportunity to survive against the enemy, the Warsaw Pact. In addition to this, NATO umbrella created the stable political atmosphere in Europe and contributed to the integration of European states over particular political themes. It can be said that NATO was particularly founded against two threats. These two threats are the Warsaw Pact and the threat of instability in Europe that has a potential of causing a war.

The ending of the Cold War triggered new debates in the international politics 
community. One of the main themes of these discussions was the future of NATO. In fact, the authors waged a scientific war against their opponents. The parts of these debates can be categorised into three positions. The neorealists (structural realists) argued that NATO would be dissolved shortly due to the absence of the threat that formed the alliances among the member states. This threat was the Soviet Union, and it was dissolved after the ending of the Cold War. (Mearsheimer, 1990, p. 52; Relations in a Multipolar World, 1990, p. 210) However, NATO still wasn't dissolved in 2017. This false prediction was a great opportunity for neoliberal institutionalist and constructivist authors to prove how realists interpret the events of the international politics falsely and how their arguments that require the existence of common external threat for alliance formation is false. Neoliberal institutionalists argued that NATO weren't dissolved due to its organisational structures, the norms and the rules that this institution created. (McCalla, 1996) Secondly, constructivist authors asserted that the shared identity among the member states was the basis of this alliance and despite the absence of the external threat, in this case, the Soviet Union, members of the alliance continue to cooperate. For them, the main reason of the alliance, in the case of NATO, was the common identity of the European civilization and the states that share this identity will continue to ally independently from the Soviet Union or any threat. (Williams and Neumann, 2000)

The three most important theoretical positions about the alliance formation over the debate of NATO underestimate or exclude the element of control management for the states in the alliance formation. One of the reasons that is put forward in the alliance formation literature is the controlling of states mutually. (Schroeder, 2004) Paul W. Schroeder evaluated the modern history of international relations in the context of alliances that were formed by the states to establish mutual control mechanisms. The advocates of control management approach is not limited with Schroeder. There are some other authors who underline the importance of control in the formation of alliances. "Next to accretion, the most prominent function of alliances has been to restrain and control allies, particularly in order to safeguard one ally against actions of another that might endanger its security or otherwise jeopardise its interest." (Osgood, 1968, p. 22) In addition to Osgood's interpretation, Liska argued that the alliance politics of Bismarck is an exact example to understand the control behaviour of states via creating alliances with other states. (Liska, 1962, p. 116) Schroeder highlighted the importance of establishing control mechanisms while forming the alliances.

In this study, I argue that the establishment of NATO as an alliance gave the member states that are the most industrialised and the most developed countries, an opportunity to control their defence policies mutually and eliminate the possibility of emerging instability that is sourced from suspicion on the defence policies among the states. NATO has regulated the security relationships among its member states, and this regulation obstructed the possibility of the security dilemma. I defend that the control management is one of the fundamental reasons of the forming of alliances, thus the reason NATO 
did not dissolve after the Cold War is that the member states needed to determine security policies and attitudes of other states. NATO gives its members this transparency to create a secure environment of mutual dependency. I will firstly examine the main three theoretical approaches and the debate between the three most important theoretical positions over NATO after the Cold War in the context of the alliance formation literature. After that, I will analyse how control management is one of the main components of alliance formation. Secondly, I will present how control management is a fundamental part of NATO as an alliance and how its effect was for the alliance's maintenance.

Theoretical Debate Over the Alliance Formation and NATO After The Cold War

There are three main theoretical positions over the situation of NATO after the Cold War. They are structural realism, neoliberal institutionalism and constructivism. Each approach evaluated the existence of NATO in the postCold War era regarding their theoretical assumptions for cooperation among the states. The case of NATO has vital importance for these debates. NATO was established under the circumstances of the Cold War, but as an alliance, NATO continues to exist after the war. For structural realists, NATO would dissolve in a short-term future due to the lack of external threat that was the reason for the alliance. However, constructivist and neoliberal institutionalist authors thought differently. As for constructivists, they predicted that NATO would continue to exist due to its role in identity formation and for neoliberals, due to its strong, well organised institution- al structure. This contradiction among three approaches became a scientific battle. All of these three positions tried to prove their arguments on NATO. In this part, the theoretical debate between these three approaches will be adressed and be critiqued. Lastly, the control management approach will be evaluated and be introduced as the most appropriate explanation to understand the existence of NATO after the Cold War.

\section{Structural Realism}

The theoretical debates over the alliance formation and the dissolution are originally a reflection of the controversies over the balance of power theory and its critiques. (Yalçın, 2006, p. 7) This scientific clash symbolises the tension between structural realism and its opponents. For structural realists, the existence of an external threat for alliance formation is compulsory. If there is no external threat to a political unit or if the threat goes away, a political unit does not want to establish an alliance tie with the other units. This assumption automatically means that the dissolution of an alliance is dependent to the threat. (Walt, 1997, p. 158) In fact, this assumption of structural realist approach is a result of their idea of self-help state in an anarchical order. Each political unit, this unit being the state in international politics, must sustain their security and the ultimate goal of the state is to survive in the anarchical structure of international politics. The states can select to establish alliance relationships to create a security environment for themselves. In connection with this assumption, the states make alliances only against the external threats, and these alliances are made for sustaining the balance of power. This action is a major challenge for structural 
realists because both power-balancing and bandwagoning have potential risks for the states of costing their autonomy. "Joining an alliance usually reduces a state's autonomy. Accordingly, states will be reluctant to bear these costs if the alliance no longer serves a useful purpose." (Walt, 1997, p. 158)

The only measure of alliances is an external threat in the minds of structural realist authors. Walt refined this approach with adding some immaterial elements to measure the level of the external threat to understand the alliance relationships. "Alliances are most commonly regarded as a response to an external threat. The level of threat is function of relative power, geographic proximity, offensive capabilities and perceived intentions." (Walt, 1997, p. 159) Walt shows these four elements to measure the level of a threat. Firstly, he puts immaterial items such as perceived power. It is not suitable with the realist account. The structural realism highlights only the material elements of power to understand the events and phenomena of international politics. However, the intention is not a material element in the realm of international politics. On the other hand, this approach underlies some aspects to find the reasons of groupings of political units. The states make alliances, but they try to protect their autonomy. If the alliance harms the autonomy of the state, the alliance can be dissolved. In this context, it can be said that there are two reasons for the dissolution of an alliance, which are the disappearing of the external threat and the threat of autonomy among the members of the alliance. A state is very unlikely to accept the hegemonic leadership of another state unless a great ex- ternal threat is present. (Walt, 1997, p. 164) The states become allies to balance threats. (Walt, 1990)

The external threat, the balance of power and its more refined version of the balance of threat theories are widely accepted by the authors of the structural realism. On the other hand, John Mearsheimer criticises this framework in the context of great power politics. (Mearsheimer, 2002) Mearsheimer argued that the defensive approach that depicts the states as political units that only strive to sustain their security is not enough to understand great powers. The only way to maintain security for the great powers is being the hegemon. Other states cannot threat the hegemon. The most efficient way of achieving the hegemony and sustaining the security is by offence. He pointed out the United States of America as an example for it. The United States established hegemony in Western Hemisphere and followed policies to unable other states to claim power in other regions. For example, the Soviet Union couldn't be a hegemon in Europe. United States blocked the Soviet threat with the alliance of its European partners under the name of NATO. The great powers make alliances to eliminate their potential enemies' claims of power and domination. Mearsheimer accepted the significance of the external threat factor like most of the structural realist authors. In addition to this approach, he added that the great powers determine their enemies according to the potentiality of being the hegemon. The great powers have to develop alliances against these potential enemies. This assumption is the reason why he pointed out Unified Germany and China as the probable enemies of United States. He examined 
the potential enmity between China and United States extensively. For the scope of our investigation, his ideas over Germany are more important. Mearsheimer thought that NATO would dissolve. He is not the only structural realist author who defend this idea. Authoritative authors such as Stephen Walt and Kenneth Waltz share the same ideas with him. Unified Germany can become a regional hegemon for Mearsheimer, and this potentiality means an enmity between the United States and Germany. As a result of this hostility, NATO will dissolve, and European security structure will transform into the renationalised atmosphere.

As far as the approaches of structural realist authors are considered, two separate categories can be metioned. Defensive realists depict the security demand against the external threat as the main reason for forming alliances. Walt and Waltz can be counted in this category. Secondly, as an offensive realist Mearsheimer argued that the main criterion for the great powers in chosing their allies is inhibiting the enemies that have potential to become a hegemon. The great powers make alliances with the states that have no chance to become a hegemon in its region. The defensive realists argued that NATO would disperse due to the disappearing of the Soviet Union as the external threat. Furthermore, the offensive realist view predicted the same for NATO because Germany had a potential to claim hegemony in Europe and it is the reason for NATO to dissolve according to Mearsheimer. Germany will try to change the power structure, and the United States will withdraw from Europe. This withdrawing will be the end of NATO and the starting of renationalisation process in Europe's defence architecture.

The critical aspect of the structural realist theory is its focus only on the material power and material threat. This perception of power is also affected by the way threat is defined. As a result of this definition of power and threat, structural realists neglect the immaterial aspects such as intention, the density of threat or dilemmas that can occur parallel to the policies of states. In connection with this negligence, structural realist authors interpreted the future of NATO falsely. The disappearing of the external threat was sufficient for them for the dissolution of an alliance. On the other hand, the forming of alliances is not limited to the material dynamics, and it is not dependent only on the external threat as structural realists claim.

\section{Neoliberal Institutionalism}

The neoliberal authors had the second significant position about the debates on the future of NATO after the Cold War. The neoliberal views focused on the institutional capacity of NATO and its effective regulations about the security issues. For them, mainly the success of NATO or its existence after the Cold War and its existence in the changing character of the international politics is related to its institutional structure. NATO regulated the security issues that reflect the interest of the member states so that the member states continue to be the part of the alliance. For them, the continuity of the alliances is strongly related with the institutionalisation. Before the examining of the neoliberal account about NATO in post-Cold War era, the evaluation of the basic assumptions of the neoliberal institutionalism will be helpful.

One of the most prominent authors of neoliberalism is Robert Owen Keohane. 
He started examining the emerging of neoliberal account in the field of international politics with the increasing demand for the transactions between states after the World War II. (Keohane, 1984, p. 5) For him, the increasing number of transactions caused the compulsory inter-state bodies to regulate these transactions in order to define norms and rules. The international institutions were built over this necessity. The establishment of the institutions is beneficial for all parts because of that the cooperation among states "can provide information, reduce transaction costs, make commitments more credible, establish focal points for coordination, and in general facilitate the operation of reciprocity." (Keohane and Martin, 1995, p. 42) Keohane defined the institutions as "a general pattern or categorisation of activity or to a particular human-constructed arrangement, formally or informally organised." In the neoliberal account, the institutions will regulate the issues that are on the inter-state area, and as general patterns emerge, these patterns will build more certain relationships among the states.

The emerging of the general patterns and the increasing of certainty against the anarchic character of the international system creates appropriate situations for the international regimes. The policy coordination among states gains sustainable framework as a result of international regimes. For example, international monetary regime or international trade regime are of significant importance for the systemization of cooperation among states. There is a theoretical clash between realists and neoliberal institutionalists over the character of the international institutions. Neoliberals argued that as stated previously, the states become a part of the institutions due to their interests as members of the international regime. However, the realists argued that this is a liberal utopia and an illusion that was created by the liberals. They claimed the institutions to be the result of the hegemony of the United States of America. (Keohane, 1984, pp. 8-9; Morgenthau, 1954, p. 154)

Keohane argued that the institutions are not the dictation of the United States to abandon authority. However, the states choose to be a part of the institution due to the self-interest. The states are rational actors, and they pursue their benefits. The cooperation among states is formed over pursue of interest. Keohane depicts this behaviour of the states with the distinction between cooperation and the harmony. The harmony is an idea in the classical liberal thought that if every actor pursues its interest without regarding the others, this behaviour facilitates the achievements to the goals. However, the cooperation among the states is increasing the certainties in the anarchical structure of the international politics. (Keohane, 1984, p. 54) The actors cooperate to increase their benefits via the determination of certainties. The cooperation is not a natural situation like the claim of the classical liberalism, but the cooperation is constituted by the states to increase their interests. (Keohane, 1984, p. 57) "American leaders did not construct hegemonic regimes simply by commanding their weaker partners to behave in prescribed ways. On the contrary, they had to search for mutual interests with their partners, and they had to make some adjustments themselves in addition to demanding that others conform to their design." (Keohane, 1984, p. 138) 
The neoliberal account over the debate of NATO's future was shaped by the indicated institutionalist perspective. NATO can be interpreted as an institution that regulates the security issues among the states and creates and security umbrella. Under this umbrella, the member states meet in the common challenge of survival in the anarchy of the international system. This meeting is beneficial for all members of the alliance. Independent from the existence of an external threat, the alliance's persistence after the Cold War is strictly related to the providing of security by the alliance. McCalla argued that the success of the alliance was sourced from the creation of sustainable security regime for its members. (McCalla, 1996, p. 447) Secondly, NATO became significant among other examples as a military alliance. Its significance as a part of its persistence despite the changing of the conditions is its institutional capacity. The headquarters, the secretariat has an extensive developed bureaucracy. Missions other than military issues that NATO took responsibility of after the Cold War, such as peace building and the regulation of security issues in the conflict zone, which influenced the defence policy of the member states, made NATO's structure strong. (McCalla, 1996, p. 456)

On the other hand, another reason that is defended by McCalla and overall neoliberal account is the effect of the influence. The bureaucracy of NATO has different relationships with each member of the alliance. The policies that are followed by the bureaucracy of NATO as a source of detailed regulations about the security issues prevent the dissolution of the alliance. Any member thought to the dissolution due to loose these highly qualified experts to manage the security issues. This important expertise became the glue that holds the state together. It can be considered as both technical and administrative assistance on security issues. (McCalla, 1996, p. 462)

The predictions of the neoliberal account are partly true on the case of NATO in the post-Cold War era. However, it is not possible to measure the causal relationship between the persistence of NATO and its qualified bureaucracy and organisational capacity. The general principle of the neoliberal account over the debates of the alliance formation and the dissolution is organisational capabilities and the power of the organisational capacity to regulate the policy issues. However, the neoliberals introduce the alliance in a framework that is independent from the material elements of the power. For example, if the least developed twenty states come together and create a military alliance that is organisationally highly developed, and there are highly qualified experts in it, can this alliance persist? It is not easy. In the case of NATO, neoliberals choose to prove their assumptions on the best case because NATO is a unique alliance organisation that has such a strong administrative body. The causal relationship between the structure of the organisation and its persistence is not testable. There are no sufficient material elements of the neoliberal argumentation about the persistence of NATO. If NATO is considered as the unique case that can't be comparable with other alliances, this case can't be the part of the debates on alliances in the field of international politics. There must be other cases to compare and to prove that the alliance becomes long-standing coopera- 
tion only by constructing strong administrative bodies.

\section{Constructivism}

Constructivism is a structural theory in the field of international politics. Alexander Wendt counted the basic three principles of the theory. Firstly states are the major players in the international politics, parallel to the arguments of structural realism and the neoliberal institutionalism. However, constructivist thought highlights the immaterial elements of the international system much more than material forces. The inter-state relationships can be explained according to the immaterial forces of the international politics. This second component of the constructivist thought is its difference from the structural realism and the neoliberal institutionalism. Thirdly, the constructivist thought highlights the effect of social structures that shape the interests and the identities of the states. According to this argument the social structures determine the behaviour of the states. (Wendt, 1994, p. 385)

The determinant of the enmity and alignment derives from the identity in constructivist thought. In this sense, the alliances have formed the groupings of the identities accordingly. This assumption is one of the most significant critiques of the constructivism to the realist thought. The constructivist literature accused the realist authors of neglecting the constitution of actors and of focusing only on their behaviours. The shared ideas and the common knowledge among the members of the alliance determine the alliances and the enemies. (Wendt, 1999, pp. 16, 252) For constructivists, the states can come together if they share the same goals that are related to having the same identity. The dissolution of the states is dependent on the identity shift. If the identity remains the same, any external factor or a material dynamic can't change the alliance relationship. Wendt pointed out the work of Hedley Bull in which he argued that there is an anarchical system in the structure of the international politics. On the other hand, the states come together under some principles and create communities, and the rules of the communities facilitate the emerging of international society. (Bull, 2002) Wendt argued that states create groups to save their identities and they declare enmities that mean the excluding of some actors for the emerging of the society. (Wendt, 1999, p. 253) "Self mirrors Other, becomes its enemy, in order to survive. This of course will confirm whatever hostile intentions the Other had attributed to the Self, forcing it to engage in realpolitik of its own, which will in turn reinforce the Self's perception of the Other." (Wendt, 1999, p. 263)

Wendt as one of the most prominent authors of the constructivism argued that the social structures such as international society like in the mind of Bull, the alliances, the enmities and the cooperation etc. are formed by three elements. They are shared knowledge, material resources and the practices. These three elements are affected differently by the construction of the meaning of the items in the international politics. Wendt pointed out the nuclear weapons. He argued that the reason why the United States perceives the nuclear power of North Korea as a threat but the arms of the United Kingdom, which have hundred more times nuclear weapons than North Korea, harmless, means that the same material element changes the meaning accordingly to the shared knowledge and this process influenced the practices. (Wendt, 1995, p. 73) 
After the examining general characteristic of the constructivist thought, it can be beneficial to focus specifically on the security issues in this approach. Wendt addressed the distinction between the alliances and the collective security arrangements. (Wendt, 1994, p. 386) He defined the alliances as "temporary coalitions of selfinterested states who come together for instrumental reasons in response to a specific threat." (Wendt, 1994, p. 386) For him, the collective security arrangement is that "states make commitments to multilateral action against nonspecific threats." (Wendt, 1994, p. 386) For him, NATO is the example for the collective security arrangement.(Wendt, 1994, p. 386) The states can make alliances for temporary interests, and these sorts of alignments can change accordingly to the material elements or the daily threats. However, the collective security arrangements are directly the reflections of the identity, the shared knowledge and the vision among the states. This assumption shows that the persistence of NATO derives from the collective identity between the member states. (Wendt, 1994, p. 391)

Williams and Neumann's work explained the persistence of NATO despite the disappearing of the Soviet Union with the collective identity approach of constructivism. (Williams and Neumann, 2000) Williams and Neumann argued that the member states of NATO do not perceive the other member states as a threat due to the shared identity under the umbrella of NATO community. (Williams and Neumann, 2000, p. 358) In addition to this, for the authors of the article, there is a social pressure on the decision makers of the member states of NATO for the persistence of the alliance.
This social pressure stems from the security demand of the identity that created NATO. (Williams and Neumann, 2000, p. 367) Even after the collapse of the Soviet Union, the security threat to the collective identity of the member states of NATO did not decrease. If the dissolution of NATO did take place, this event would be perceived as the loss of the collective identity that forms NATO. (Williams and Neumann, 2000, pp. 367-369) “NATO’s power cannot be reduced to this. Indeed the power of the Alliance in the post-Cold War period derives in considerable part from the ability to maintain its military dimension while at the same time combining that dimension with a powerful cultural and political narrative that overcame the challenges faced by a purely military representation of the Alliance." (Williams and Neumann, 2000, p. 386)

Constructivism focuses on the social representation and social constitution of events in the international politics. In the subject of the alliance formation, the distinction between the alliances and the collective security arrangements must be addressed. This classification with reference to the temporality is not measurable. The limits of temporality and why the alliances are named as the reflection of temporary situation as a contrast to collective security arrangement can't be accordingly defined to a measurable scale. It seems the inclusion of alliances phenomenon to the constructivism rather than trying to explain the reality with the tools of theoretical outlook. Wendt's theoretical distinction affected the ideas of Williams and Neumann who construct their arguments on the existence of the security demand that is based on the European identity against the global threats. The dimensions and 
the discourses of new threats were explained only with reference to the events that are out of Europe. The European national identities created two biggest wars in the history of humanity. If the identity is the base of collective security arrangements differently from the alliances, why the renationalisation of the defence policies of European states does not take place as Mearsheimer claimed? National identities have also strong effects over the constitution of political identity. However, to explain the persistence of NATO, the national identities are neglected against the civilizational discourse. Europe needs NATO due to the threats on its civilizational values and identities.

As Wendt indicated the identity requires the self and the determination of the other as opposed to the self. In the context of post-Cold War era, the atmosphere of European security seems more appropriate for the rediscovery of national identity in the situation of lack of external threat. The figures like Saddam or the terrorist organisations as challenges to European states can be overcome individually. However, the members of NATO chose to remain in the organisation as a result of the social pressure of security demand. The constructivist approach on the alliances does not give a theoretical explanation of the phenomenon rather than try to explain the cases by using the theory because of that the renationalisation of European defence policy and the remaining under the umbrella of NATO have equal opportunity if the only criterion is the identity constitution of states. The constructivist approach can't produce a sustainable explication in the subject of the alliances and especially in the case of the persistence of NATO.

\section{Control Management Approach}

The main theories of international politics that are generally indicated and in the context of the alliance formation and the dissolution have some vulnerability as stated in previous parts. In this research, I defend the theoretical framework of Schroeder(Schroeder, 2004) who argued that the states make alliances to control the other states. I am implementing this argument to the debates over the persistence of NATO. As a result of this assumption, the alliance organisations that are formed by multiple states are the multilateral control mechanism for the states. The members of the alliance get a chance to observe other states and can be confident towards the others. The management approach of Schroeder gives an opportunity to understand the alliances in the context of both material and immaterial aspects and this theoretical approach is appropriate to understand the pertinence of NATO after the Cold War. In this part, the control management approach of Schroeder will be examined, and in the following part, the case of NATO will be discussed with the theoretical tools of the approach of Schroeder.

Schroeder's ideas are renowned and celebrated in the area of international politics. In his article, “1815-1945: Weapons of Power and Tools of Management”, he discussed the alliance relationships between states from the starting era of modern politics to the end of the Cold War. He argued that the states do not make alliances only for the balance of power, for the threat or bandwagoning. The states form alliances to influence each other and control the behaviour of the other states. There is an inverse proportion between the autonomy and the 
control. The states use the alliances to control other states while loosing some part of autonomy and Schroeder focused on this inverse proportion between two notions in the inter-state relationships. (Wetzel et al., 2004, p. 7)

Schroeder highlighted the term of casus foederis of the treaty between the states. The states that sign such a treaty declare that these states do not fight against each other and also if a third part wages war against a state that is a part of the treaty, other parts of the treaty will help their ally. This principle serves to sustain the demand of security by the alignment of the states. In addition to this, the states can get a chance to observe themselves in the sense of the aggregation of power and the emerging of intentions. The relationships give states the chance to discern both the power and the intention of other states. (Schroeder, 2004, p. 195) "Most recognise additional purposes of alliances as well -those of legitimating one's own regime or that of an ally, preventing revolution or internal disturbances, spreading an ideology, or enhancing a state's influence and status, for example." (Schroeder, 2004, p. 195)

The alliances in the mind of Schroeder have two faces. One of them is alliances as the weapons of power and secondly alliances as tools of management and control as indicated in the title of his article. He pointed out firstly Bismarck as one of the first executers of this policy. For him, Bismarck used the alliances as a weapon to get the chance to control the intentions of another state. Schroeder evaluated the control management via forming alliances as the basis of achievement for the unification of Germany.

After the analysis of Bismarck, Schro- eder analysed the control management of alliances in European history of international politics. He depicted five assumptions to illustrate this theoretical approach. Schroeder argued that the external threat is not always essential for an alliance to arise. The states make alliances neither for need nor the aggregation of power, but the states form the alliances to influence or control the other states. Secondly, in some alliances, the nominal aim of the alliances in the treaty is different from the intentions of the state. Thirdly, the alliance gives an opportunity to restrain the policy options of the partners. Fourthly, the alliances serve to isolate the states that are out of the treaty. These isolated states go through very disadvantageous positions. The states can create disadvantageous political positions for other states. Fifthly, the states perceive a threat from another state and try to ally to prevent a threat. Schroeder argued that a state can establish a control management relationship with the other state as a result of one or multiple of these five circumstances. (Schroeder, 2004, pp. 198-199)

After the theoretical assumptions over the alliances, Schroeder interpreted the modern history of Europe until the end of Cold War in the framework of the control management approach. (Schroeder, 2004) He examined the cases of the Holy Alliance of 1815, The German Confederation, Western-Soviet Alliance and the United States among the Cold War. In the Holy Alliance, Schroeder argued that the alignment between Austria, Prussia and Russia gave the partner states an opportunity of deterrence. These states could control the intentions of each other and sustained for themselves confidential environment in 
the age of revolutions, liberalisation and nationalisation. With the effect of deterrence, these three states can intervene the European states where the revolutionary movements are strong to prevent the spreading of these ideas. (Schroeder, 2004, p. 199) The second historical case that Schroeder examined was the German Confederation of 1815 . The confederation was organised to save German states and Austria from the threat of France. At first, the alliance was formed for a defensive goal and against an external threat. On the other hand, in the 1830 s the alliance was used by Metternich to control German states and especially Prussia. Metternich could control Prussia in European politics.(Schroeder, 2004, p. 200) The third example of Schroeder was on the Western-Soviet alliance. He stated that the alignment between these two camps was never possible in 1939 due to the inability to share control. For him, both parts couldn't believe that the parts could control themselves in an alliance. The invasion of the Baltic states by the Soviet Union and the tension between Western European powers and the Soviet Union over Poland created these unconfident relationships. As a result of this insecurity about the control in a potential alliance caused the rising of Germany at the middle of these two political camps. (Schroeder, 2004, p. 218) Lastly, Schroeder embraced the case of the United States among the Cold War. He argued that the United States focused on the strategy of total victory. As a result of this strategy, the United States made alliances with the Soviet Union and Western European powers against Germany and Japan. On the other hand, the grand strategy of the United States was to establish control over its allies after the post war so that any ally couldn't try to enlarge its interest after the war. In addition to this, any attempt for the power enlargement can have potential for prospect wars that mean a threat to sustainable peace environment after the World War. The ending of the Cold War made the control of the United States over both the victorious and defeated sides possible. This control was not only limited to the military power but also the values of the United States from life style to economic production and trade were spread to these countries. NATO was an example of these control mechanisms over Europe in the field of defence policy. "Such analysis should look for other motives and purposes besides the standard ones of mutual security and capability-aggregation -in particular, for the desire to control one's ally, the aim of managing an international problem, and even the hope of avoiding conflict by allying oneself with a rival. In any case, the way in which mutual control or influence is exercised is always important for the durability and effectiveness of an alliance." (Schroeder, 2004, p. 221)

The control management approach as an alliance formation theory gives an opportunity to evaluate the material and immaterial elements of the international politics at the same time. This synthesis means that the material threat can be considered an accordingly concrete event in the political realm but also the investigating of the different appearances of meaning becomes possible. Secondly, the alliances can be regarded as a form of regulation and the increasing of determinacies in an anarchical structure. However, the struggle among the allies continues to exist, and the international regimes carry some nuances in comparison with the government 
regulations. The control management approach of Schroeder gives a possibility to overcome these tensions over the alliance formation theories. In the following part, the case of NATO in post-Cold War era will be discussed in the context of the control management approach.

\section{NATO As A Control Management Platform}

The control management approach exists partially in the works of many authors. For example Walt expressed that the alliances give an opportunity to the parts of the agreement for conducting or steering the policies of the other states. (Walt, 1997, p. 158) However, Schroeder puts the intention of the control and the influences of the parts of the alliances mutually on the center of his investigations. In this part, several themes over the discussions of NATO in the post-Cold War era will be examined to introduce how NATO is at the same time a platform of control management for its members.

The structure of the security in NATO is significantly different from most of the military alliances. Its significance is the indivisible character of the security among its members. The members of NATO declared that these states do not fight against each other and all of the member states will defend their allies against a threat of a third party. (Weber, 1992, p. 633) This kind of security order requires an effective cooperation and collaboration in the military issues. The joint task forces, joint military exercises, common arm trading etc. exist in the structure of NATO because each state established transparent military bodies among the members of the alliance.(Snyder, 2011, p. 485) As the result of this military structure and the vision of cooperation in military issues in NATO, the member states can disagree over some policy issues. However, the control mechanism holds together the member states. Although a member state observes that the executions of the alliances are contrasted to its interest, it persists to remain in the alliance due to the opportunity of the control management mechanisms within the alliance. (Snyder, 2011, p. 485)

The official texts of NATO over the foundation and the development of the organisation show the different dimensions of control management mechanisms. Firstly, NATO rejected officially a widely known assumption about the alliance that NATO was established only against the Soviet Union. In the official history of the alliance, it is stated that "It is often said that the North Atlantic Treaty Organization was founded in response to the threat posed by the Soviet Union. This is only partially true. In fact, the Alliance's creation was part of a broader effort to serve three purposes: deterring Soviet expansionism, forbidding the revival of nationalist militarism in Europe through a strong North American presence on the continent, and encouraging European political integration." (NATO Public Diplomacy Division, 2010, p. 1) The Soviet Union as an external threat was only one reason for the establishment of the alliance. Other two are to avoid the renationalisation of defence policies and to contribute to the integration in Europe as stated in the document. These two foundational reasons show that NATO symbolises a platform for the new inter-state relationships among the European states in multi-level from economy to politics. The establishment of such relationships requires the confidence among the member states and 
joint management mechanisms firstly. NATO is placed as the initiator of the integration processes in the continent after the atmosphere of the post-World War era. "European states still needed confidence in their security, however, before they would begin talking and trading with each other. Military cooperation and the security it would bring would have to develop in parallel with economic and political progress." (NATO Public Diplomacy Division, 2010, p. 1) Under favour of the confidence of the control mechanism and the security as a result of the establishment of NATO, the member states started to trade. The increasing amount of the growth in the economical field and the integration of Europe contributed to the rehabilitation of the markets. The control management mechanisms of NATO provide appropriate security architecture for the growth of European markets in the context of integration. The security integration and the establishment of control mechanisms progressed parallel to the emerging of market integration in Europe. "In 1948 Congress buttressed the Marshall Plan by creating the Economic Cooperation Administration (ECA) to help a common market in Western Europe, to assist in restoring the economies of Europe." (Duignan, 2000, p. 2) The Marshall Plan that is created by President Truman is not limited to the direct military and economic aids but also an initiator of control mechanisms among the allies. This role of NATO can be seen obviously in the official documents of the alliance. In the official history of the alliance that was published by the public diplomacy division, it is stated that the reasons of the enduring of NATO are the deterring of militant nationalism and providing collective security for the democrati- sation and the integration of Europe. (NATO Public Diplomacy Division, 2010, p. 5) NATO is not limited to the military policies, but under the umbrella of the alliance, the member states found the opportunity to observe each other and try to establish confident relationships for trading and political cooperation issues over the control mechanisms.

Another reason of the enduring NATO after the ending of the Cold War is its significant role in the transatlantic cooperation between European states and the United States of America. There is not a more efficient platform to regulate the control mechanisms among these states. Hellmann and Wolf argued that NATO serves as the only institution in the level of governments for the cooperation between the United States and European countries. "NATO remains the only institution for American and European officials to communicate daily at all levels of government. These channels of communication will ensure that decision-makers take the interests of other states into account when formulating their policies." (Hellmann and Wolf, 1993, p. 21) This transatlantic cooperation and the presence of the United States in Europe is evaluated as important to the sustainability of the control mechanisms due to the role of the United States as an external actor in the European continent. The establishment of sustainable control mechanisms between the states is a difficult process. In addition to the challenges of the processes, the states in Europe had long-standing historical, political and military conflicts with each other that create additional problematic dimensions for both the alliance formation and the forming of control management tools. The involvement of the 
United States into the European politics facilitated the establishment of control mechanisms while creating a sustainable, peaceful security environment in Europe. The participation of the United States carries another importance for managing several problematic areas in Europe such as inhibiting the atomization of European states because of the chronic security problems, German hegemony, the tensions between Germany and France, the transition of Eastern European countries towards democracy and market economy. If the European countries face these challenges without the mentioned control mechanisms, the states can be divided into different camps, and the sustainable peace can't be possible. "In the case of NATO, however, they coalesced because their security was assured by a powerful outsider that delivered both external protection and internal order to Western Europe." (Art, 1996, p. 8)

The renationalisation of European political landscape is an important discussion in early debates after the Cold War. For example, the renationalisation and the establishment of multi polar order in Europe were the important dimensions of Mearsheimer's pessimist arguments over the international politics after the Cold War. (Mearsheimer, 1990) The renationalisation is strictly related to the disappearing of the control mechanisms among European states. The member states have fear over this potential danger in the continent. "These elites feared that their security and defence affairs would retrogress from multilateralism to nationalism-from the multilateral, transparent, and cooperative approach that had been achieved within NATO under forty years of Amer- ican leadership to a nationalistic, competitive, autonomous, non-cooperative approach." (Art, 1996, pp. 4-5) The existence of NATO as a control mechanism removed the fears over security issues and gave a sustainable platform to share ideas about the prospect challenges of the new conditions in European politics.

The place of the ex-communist states in Europe is another reason for the enduring of NATO in post-Cold War era. The eastern European countries had communist regimes during the Cold War, and Berlin Wall was the symbol of the distinction between two camps of European states. After the dissolution of the Soviet Union, these states declared their independence. However, its involvement in the European politics and the management of this process requires a sustainable control mechanism otherwise the political structure of Europe was appropriate for the renationalisation of defence policies. The independence processes of the new states could cause new groupings, and these groupings could harm the security environment. The enduring of NATO inhibits the renationalisation and sustained control mechanisms for the member states. In addition to this, as the result of the enlargement processes, ex-communist states became a part of the alliance, and their involvement facilitated both their adaptation to this security environment and the democratic rules. Most of these countries became the member of the European Union at the end of this process. Talbott explained this process in three steps.(Talbott, 1995, pp. 1-2) The integration problem of the eastern European countries did not harm the security architecture of Europe, rather, after the involvement of these countries to NATO 
alliance the security architecture of Europe became more strengthened. Firstly, the outsider effect of the United States saved the control management mechanisms of NATO with its hegemonic power and the distribution of power among European states would not be affected by this process. The status quo would not change. Secondly, NATO as a control mechanism shared the knowledge, the ideas and the identity for the transformation in these countries. NATO was the management platform of this process. Otherwise, if the sharing of knowledge and the formation of identities weren't possible, the fragmentation among European states could increase. Thirdly, such a huge transformation could reveal power gaps, conflicts or political disagreements both in the alliance and outside the alliance. NATO offers an opportunity to manage this transformation.(Talbott, 1995, pp. 1-2) All of this processes made changes in some structural elements of NATO beyond a military alliance. NATO started to focus more on peace keeping and the spreading of liberal values to the member countries especially for the new members of the alliance from eastern European states. "The NATO Alliance remains the principal mechanism for American involvement. But if NATO is to continue to be useful, it will have to adapt to the post-Cold War era-and that, in turn, means that NATO must promote and consolidate democratic and free market values." (Talbott, 1995, p. 2)

Up to this point, the role of NATO as a platform of control management was examined at the level of units. In addition to unit level analysis, focusing on the systematic level can be beneficial. I argue that the systematic conditions of the international system facilitated the existence of NATO in post-Cold era because unipolar structure as was the case after the Cold War, increased the necessity for a control mechanism especially between the super power and the secondary powers. The international system transformed into a unipolar structure after the dissolution of the Soviet Union. The structural conditions of the international system will be affected by the behaviour of the alliances. Before the examination of the case of NATO, a theoretical evaluation of the alliances in unipolarity will give us a general outlook to illustrate the case. There is not many specific works on the conditions of alliances in the unipolar international system. One of the most comprehensive works on the subject belongs to Hasan Basri Yalcin. He argued that the alliances are established under the unipolar structure against instability.(Yalçın, 2006, p. 8) If the definition of the unipolarity is considered, the assumption can be more obvious. He defined the unipolarity as "the existence of a sole superpower operating on the global scale with a more central role, the absence of a counter power, and the difficulty of forming a counterbalancing coalition."(Yalçın, 2006, p. 9) In this condition, the states try to save the stability because only the superpower has the capability to change an element in the system. There is no other state with such a capability. The secondary states can collaborate to persuade or enforce the superpower against a change that is done by the superpower. However, it is a very risky attempt because such an alliance against the superpower can't be formed. (Yalçın, 2006, p. 10)

The case of NATO after the Cold War is an obvious example of the theoretical assumption of Yalçın. The United States 
remained as the only super power after the dissolution of the Soviet Union. Other members of NATO, tried to inhibit the changes that can harm their interests. All states tried to inhibit the change and the alliance as a control management tool transformed into the platform of the negotiation of this process. NATO gained one more importance as a transatlantic cooperation. The European States and the United States got a chance to discuss the dynamics of the new era while saving the stability. The alliance overcame the events that carry the potential to harm the stability such as the Bosnian War. In addition to this, NATO played a major role in the inclusion of eastern European countries in the democratic states and European market. If NATO did not exist or dissolved after the ending of the Cold War, the determination of the bases of the inclusion processes of eastern countries could cause instabilities in the power distribution for the member states of NATO. As a consequence of this potential threat, the member states chose to remain under the umbrella of the alliance to save the stability in a unipolar structure. In other words, NATO provided a sustainable framework to save stability and to manage the transformation of European politics at the same time. The structural cause of the enduring of NATO after the ending of Cold War is the stability demand of the system. The Cold War ended and the structure of the international system was changing. One super power, the Soviet Union, dissolved and one super power remained solely on the stage. This transformation means the transition to a unipolar structure that requires the negotiation channels between super power and the secondary powers. NATO as a military alliance worked as the nego- tiation platform to manage the challenges and the opportunities of the system. In addition to this, NATO provided the demand of negotiation. This function of NATO roots in the characteristics of alliances. The member states could control the behaviour of other states sufficiently and this active control prepared the appropriate conditions to save the stability in European security environment. The necessity for NATO was not decreased after the ending of the war, rather this necessity gained new dimensions to manage the power distribution in the post-Cold War era.

\section{Conclusion}

As indicated in the introduction, there is an enormous literature on the alliance formation but limited one for the dissolution of the alliances. In this literature, mainly three theoretical approaches dominate the debates. The structural realism focuses on the balance of power and its other versions such as the balance of threat or the balance of interest. The main characteristic of the structural realism is the system approach. On the other hand, most of the neorealist authors explain the alliances at the unit level. The systematic approach to the alliance formation is limited even among the neorealists. For example, the works like Yalçın did are an exception in the literature.(Yalçın, 2006) Although several writers add some immaterial dimensions to understand the roots of the alliance formation, the main focus of the realists is the material elements of power. The sole reason for the alliance is the common external threat, and the enduring of the alliances is strictly related to the existence of the threat. Otherwise, the member of the alliance can't find an actor to balance 
whatever they do for power, threat or interest. This approach doesn't explain the enduring of NATO after the Cold War. Despite the dissolution of the Soviet Union as the common external threat, NATO continues to exist. Furthermore, the neorealist authors such as Waltz and Mearsheimer argued the dissolution of NATO due to the changing of the threat perception in parallel to the transformation of the international system from bipolar to the multipolar. The problem of the neorealist theory is its material and the threat-centric approach. However, there are also the immaterial elements of both the power and the threat. As Wendt pointed out, the same material, nuclear arms, that belong to the United Kingdom and North Korea mean differently. The nuclear arms of United Kingdom are interpreted to save the stability of the world however the nuclear arms of North Korea are evaluated as the initiator of the doomsday. (Wendt, 1995, p. 73)

The neoliberal institutionalist theory and the constructivist theory represent the opposite side of the neorealist material centric approach. These two theoretical perspectives give respectively an importance to the management of international regimes by the institutions and the identity. One of the consequences of the opposition of these approaches to the neorealist theory is over the debates of the NATO's future. Despite the claim of dissolution, most of the neoliberal institutionalist and the constructivist authors defended the enduring of NATO. The neoliberal institutionalist authors claimed that the institutional capacity of NATO to manage the international security regime and its highly qualified bureaucracy was successful to organise the management of this regime. The in- stitutional capacity is only the reason for the enduring of an alliance. I think that this claim seems very logical at first sight. However, NATO is the best and only one case to prove this argument because there is no institution to compare to it. For example, did Warsaw Pact dissolve due to its undeveloped institutional capacity? The institutional capacity can't be measured, and in the case of NATO, the impact of the institutional capacity isn't comparable.

The second opposite argument to neorealist approach is from the constructivist theory. The constructivist authors claim that an alliance is an outcome of a common identity among the states. It is the same in the case of NATO. The member states of NATO built such a military alliance as a reflection of the European identity and to save this identity against the enemies. The existence of the alliance is strictly dependent on the identity and the threat to this identity. NATO endures against the threat to European security environment. This explanation is vulnerable in two dimensions. Firstly, the constructivist approach doesn't explain France and Greece's leaving the alliance. Did these countries leave also from the European identity? Secondly, after the dissolution of material threat, the Soviet Union, why the nation states continue to behave accordingly civilizational identity rather than national security identity?

I defend that the states make alliances to build control management systems rather than against a threat, as a reflection of an identity or to regulate international regimes. NATO was a perfect example as a platform that gives an opportunity for mutual control to the states. The control management mechanism functions in two ways. Firstly, 
the states define the limits of sharing, responsibilities in common actions, for example, common defence in NATO. To achieve the goals, states share their knowledge, their capabilities, their defence policy plans, at last, they don't construct defence walls to cover their intentions for their allies. The states give some parts of their autonomy to sustain the knowledge about the intentions of other states. Secondly, the control management mechanisms are advantageous to establish stable relationships between the super powers and the secondary powers. Both sides share their intentions, policies, capacities and plans over the security issues. As a result of this negotiation platform, the super power can't behave individually and impose its agenda solely to secondary powers. On the other hand, the super power increases the amount of certainty in the dynamics of the system against the grouping of secondary powers. In a unipolar structure, control mechanisms gain more importance because the secondary powers scare the imposition of policies from the super power. On the other hand, an alliance system in a unipolar structure prevents the breaking down of the stability.

NATO is an alliance system that two functions of control management system can be observed clearly. The member states implemented the common defence policies and created accountable security decision-making processes among them. This framework gave the member states an opportunity to control the security intentions mutually. Secondly, NATO was constituted as a negotiation platform between the United States as a super power and the European powers. The states could manage the stability in the dynamic and transforma- tive atmosphere of the post-Cold War period. NATO endures after the Cold War due to its characteristic of being a control management mechanism.

\section{Bibliography}

Art, R.J., 1996. Why Western Europe Needs the United States and NATO. Polit. Sci. Q. 111, 1-39.

Bull, H., 2002. The anarchical society : a study of order in world politics. Palgrave, Basingstoke.

Duignan, P., 2000. NATO Its Past, Present and Future. Hoover Institution Press, California.

Hellmann, G., Wolf, R., 1993. Neorealism, Neoliberal Institutionalism and the Future of NATO. Secur. Stud. 3, 3-43.

Keohane, R.O., 1984. After Hegemony: Cooperation and Discord in the World Political Economy. Princeton University Press, New Jersey.

Keohane, R.O., Martin, L.L., 1995. The promise of institutionalist theory. Int. Secur. 20, 39-51.

Liska, G., 1962. Nations in Alliance: The Limits of Interdependence. John Hopkins Press, Baltimore.

McCalla, R.B., 1996. NATO’s Persistence after the Cold War 50, 445-475.

Mearsheimer, J.J., 2002. The tragedy of great power politics. W. W. Norton, New York.

Mearsheimer, J.J., 1990. Back to the Future: Instability in Europe after the Cold War. Int. Secur. 15, 5-56.

Morgenthau, H.J., 1954. Politics among nations. Alfred A. Knopf, New York. 
NATO Public Diplomacy Division, 2010. A Short History of NATO.

Osgood, R.E., 1968. Alliances and American Foreign Policy. John Hopkins Press, Baltimore.

Relations in a Multipolar World, 1990. . U.S. Congress, Senate, Washington D.C.

Schmitt, C., 2008. The concept of the political. University of Chicago Press, Chicago.

Schroeder, P.W., 2004. Alliances, 1815-1945: Weapons of Power and Tools of Management, in: Systems, Stability, and Statecraft: Essays on the International History of Modern Europe. Palgrave Macmillan, London, pp. 195-222.

Snyder, G.H., 2011. The Security Dilemma in Alliance Politics. World Polit. 36, 461-495.

Talbott, S., 1995. Why NATO Should Grow. N. Y. Rev. Books.

Walt, S.M., 1997. Why alliances endure or collapse. Survival 39, 156-179.

Walt, S.M., 1990. The Origins of Alliances. Cornell University Press, London.

Waltz, K.N., 1979. Theory of international politics, Addison-Wesley series in political science. Addison-Wesley, Reading.

Weber, S., 1992. Shaping the postwar balance of power: multilateralism in NATO. Int. Organ. 46, 633-680.

Wendt, A., 1999. Social Theory of International Politics. Cambridge University Press, Cambridge.

Wendt, A., 1995. Constructing International Politics. Int. Secur. 20, 71-81.

Wendt, A., 1994. Collective Identity Formation and the International State. Am. Polit. Sci. Rev. 88, 384-396.
Wetzel, D., Jervis, R., Levy, J.S., 2004. Introduction, in: Systems, Stability, and Statecraft: Essays on the International History of Modern Europe. Palgrave Macmillan, London, pp. 1-19.

Williams, M.C., Neumann, I.B., 2000. From Alliance to Security Community: NATO, Russia and the Power of Identity 29, 357-387.

Yalçın, H.B., 2006. Alliance Formation under the Unipolar Structure: the Case of Turkish-US Alliance in the Second Gulf War (Master of Arts). Koç University, Istanbul. 